\title{
Flavone-Rich Fractions and Extracts from Oroxylum indicum and Their Antibacterial Activities against Clinically Isolated Zoonotic Bacteria and Free Radical Scavenging Effects
}

\author{
Patchima Sithisarn ${ }^{1}$, Piyanuch Rojsanga ${ }^{2}$ (D) and Pongtip Sithisarn ${ }^{3, *}$ (D) \\ 1 Department of Veterinary Public Health, Faculty of Veterinary Medicine, Kasetsart University, \\ Bangkok 10900, Thailand; fvetphs@ku.ac.th \\ 2 Department of Pharmaceutical Chemistry, Faculty of Pharmacy, Mahidol University, \\ Bangkok 10400, Thailand; piyanuch.roj@mahidol.ac.th \\ 3 Department of Pharmacognosy, Faculty of Pharmacy, Mahidol University, Bangkok 10400, Thailand \\ * Correspondence: pongtip.sit@mahidol.ac.th; Tel.: +66-26448701
}

check for

updates

Citation: Sithisarn, P.; Rojsanga, P.; Sithisarn, P. Flavone-Rich Fractions and Extracts from Oroxylum indicum and Their Antibacterial Activities against Clinically Isolated Zoonotic Bacteria and Free Radical Scavenging Effects. Molecules 2021, 26, 1773. https://doi.org/10.3390/

molecules 26061773

Academic Editor: Raphaël E. Duval

Received: 2 March 2021

Accepted: 19 March 2021

Published: 22 March 2021

Publisher's Note: MDPI stays neutral with regard to jurisdictional claims in published maps and institutional affiliations.

Copyright: (c) 2021 by the authors Licensee MDPI, Basel, Switzerland. This article is an open access article distributed under the terms and conditions of the Creative Commons Attribution (CC BY) license (https:// creativecommons.org/licenses/by/ $4.0 /)$.

\begin{abstract}
Oroxylum indicum extracts from the seeds collected from Lampang and Pattani provinces in Thailand, and young fruits and flowers exhibited in vitro display antioxidant and antibacterial activities against clinically isolated zoonotic bacteria including Staphylococcus intermedius, Streptococcus suis, Pseudomonas aeruginosa, $\beta$-hemolytic Escherichia coli and Staphylococcus aureus. The orange crystals and yellow precipitates were obtained from the preparation processes of the seed extracts. The orange-red crystals from the seeds collected from Lampang province exhibited strong in vitro 2,2-diphenyl-1-picrylhydrazyl (DPPH) scavenging effects $\left(E_{50}\right.$ value $\left.=25.99 \pm 3.30 \mu \mathrm{g} / \mathrm{mL}\right)$ and antibacterial effects on $S$. intermedius and $\beta$-hemolytic E. coli while the yellow precipitate from the same source exhibited only antioxidant activity. Quantitative analysis of phytochemicals in O. indicum samples by spectrophotometric and HPLC techniques showed that they contained different amounts of total phenolic, total flavonoid and three major flavones; baicalin, baicalein and chrysin contents. Young fruit extract, which contained low amounts of flavone contents, still promoted antibacterial effects against the tested bacteria with $\mathrm{IC}_{50}$ values lower than $1 \mathrm{mg} / \mathrm{mL}$ and MIC values between 4 to $10 \mathrm{mg} / \mathrm{mL}$ in $S$. intermedius, $S$. aureus and $S$ suis while higher $\mathrm{IC}_{50}$ and MIC values against $P$. aeruginosa and $\beta$-hemolytic E. coli were found. From scanning electron microscopy, the extract of the young fruit of $O$. indicum promoted morphological changes in the bacterial cells by disrupting the bacterial cell walls, inducing leakage of the cellular content, and generating the abnormal accumulation of cells. The mechanism of action of the extract for this antibacterial effect may be the disruption of the cell membrane and abnormal cell aggregations. Regression analysis of the results suggests the correlation between total phenolic and total flavonoid contents and antioxidant and antibacterial effects. Baicalin was found to have a high correlation with an inhibitory effect against $\beta$-hemolytic E. coli while three unidentified peaks, which could be flavones, showed high correlations with an inhibitory effect against $S$. intermedius, S. suis, P. aeruginosa and S. aureus.
\end{abstract}

Keywords: Oroxylum indicum; zoonotic infection; mechanism of action; flavone; HPLC; DPPH; scanning electron microscopy

\section{Introduction}

Pheka (Oroxylum indicum (L.) Benth. ex Kurz) is a plant in the Bignoniaceae family which has been traditionally used for many medicinal purposes [1,2]. Young fruits of this plant can be consumed as vegetables while the mature seeds are the components in a traditional drink. Some flavonoids such as baicalein, biochanin A, oroxylin A, chrysin, apigenin, and their glycosides such as baicalein-7-O-diglucoside, scutellarein-7-O-glucopyranoside and chrysin-7-O-glucuronide have been recorded from various parts of this plant including the pods, the seeds, and the root bark [3-10]. The amount of flavonoids in the extracts 
from the seeds and the fruits of $O$. indicum were quantitatively analyzed using a highperformance liquid chromatography (HPLC) technique [11-13], while the chrysin contents in the seed samples collected in Thailand were quantitatively analyzed using a thin layer chromatographic (TLC) densitometry technique [14]. Alkaloids and triterpenes were also found in the seeds and pods $[5,15]$. The seed oil contained some fatty acids such as lauric, myristic, palmitic, stearic, oleic, and linoleic acids [1] while some phenolics such as anthraquinone, tannic acid and ellagic acid, alkaloids, and some phytosterols were reported in the leaves $[3,4,16-18]$.

The leaf and fruit extracts of $O$. indicum were reported to reduce breast cancer cell growth, cell viability and cell migration [19]. Fresh pod 95\% extract of this plant exhibited in vitro antioxidant activities and suppressed LPS plus IFN-c-activated reactive oxygen species generation in RAW264.7 macrophages [20]. The extract also showed potent antiinflammatory action through suppressing nitric oxide and interleukin-6 secretion, due to its ability to scavenge intracellular reactive oxygen species and the alteration of signals relating to the activated lipid and protein determined by synchrotron radiation-based Fourier transform infrared (SR-FTIR) spectroscopy [20]. The hexane extract of the bark exhibited inhibitory effects on Escherichia coli and Staphylococcus aureus [21]. The $80 \%$ ethanol extract of $O$. indicum seeds exhibited an inhibitory effect on multidrug-resistant $S$. aureus [22]. Our previous reports demonstrated that ethanol extracts from $O$. indicum fruits and seeds exhibited in vitro antibacterial activities against clinically isolated Staphylococcus intermedius and Streptococcus suis and showed in vitro antioxidant activity as tested by the 2,2-diphenyl1-picrylhydrazyl (DPPH) scavenging method [23]. Baicalin, baicalein and chrysin were found to be the active compounds [12,24]. Extracts from various plant parts of O. indicum including the leaves, flowers, seeds, stalks, and tissue-cultured plants and callus exhibited in vitro antioxidant activities with high total phenolic and total flavonoid contents and baicalin, baicalein, and chrysin as the major compounds [24]. The shoot extract from tissue-cultured plant at week 3 (cotyledon stage) contained high amounts of baicalin $(14.78 \% w / w$ of the extract) while baicalein and chrysin were found in lower amounts [25]. Quantitative analysis of flavone contents by the HPLC method and investigation of in vitro antioxidant and antibacterial effects of some extracts and fractions from $O$. indicum samples and the study of mechanism of action using scanning electron microscopic technique were conducted.

\section{Results}

\subsection{Determination of In Vitro Antioxidant Activity of O. indicum Samples Using DPPH} Scavenging Method

Young fruit and flower extracts of O. indicum (OIYF and OIFL, respectively) appeared as dark brown semisolid extracts while $O$. indicum seed extracts from Lampang and Pattani provinces (OISL and OISP, respectively) appeared as semisolid dark green extracts. Yellow precipitates from O. indicum seed collected from Lampang and Pattani provinces (OIYL and OIYP, respectively) appeared as light yellow solid while OIRL and OIRP were orangered crystals from O. indicum seeds collected from Lampang and Pattani provinces, respectively.

From the results (Table 1), the orange-red crystals OIRL and yellow precipitates OIYP exhibited the strongest 2,2-diphenyl-1-picrylhydrazyl (DPPH) scavenging activities with $\mathrm{EC}_{50}$ values of $25.99 \pm 3.30$ and $29.16 \pm 0.07 \mu \mathrm{g} / \mathrm{mL}$, respectively. Seed extract OISP, yellow precipitates OIYL and orange-red crystals OIRP also promoted good DPPH scavenging effects while seed extract OISL, young fruit extract OIYF and flower extract OIFL promoted lower DPPH scavenging effects. OIRL, OIYP and OIYL which promoted strong DPPH scavenging effects, contained high total phenolic and total flavonoid contents ( $>6 \mathrm{~g} \%$ in the extracts). 
Table 1. Flavonoid Contents in O. indicum Extracts as Determined by high-performance liquid chromatography (HPLC).

\begin{tabular}{|c|c|c|c|c|c|c|c|}
\hline \multirow{2}{*}{ Sample } & \multirow{2}{*}{$\begin{array}{l}\text { DPPH Assay } \\
\left(\mathrm{EC}_{50}, \mu \mathrm{g} / \mathrm{mL}\right)\end{array}$} & \multirow{2}{*}{$\begin{array}{c}\text { TPC } \\
\text { (g\% GAE) }\end{array}$} & \multirow{2}{*}{$\begin{array}{c}\text { TFC } \\
\text { (g\% QE) }\end{array}$} & \multicolumn{4}{|c|}{ Content ( $g \%$ in the Extract) $*$} \\
\hline & & & & Baicalin + B0 & Baicalin & Baicalein & Chrysin \\
\hline OIRL & $25.99 \pm 3.30^{a}$ & $8.20 \pm 0.31^{a}$ & $6.01 \pm 0.41^{\mathrm{a}}$ & $12.12 \pm 0.02^{a}$ & $6.82 \pm 0.04^{\mathrm{a}}$ & $1.12 \pm 0.01^{\mathrm{a}}$ & $1.49 \pm 0.01^{\mathrm{a}}$ \\
\hline OIYL & $54.57 \pm 5.76^{b}$ & $6.94 \pm 0.34^{b}$ & $6.56 \pm 0.49^{b}$ & $7.93 \pm 0.06^{b}$ & $1.62 \pm 0.04^{b}$ & $1.06 \pm 0.01^{\mathrm{b}}$ & $2.34 \pm 0.03^{b}$ \\
\hline OISL & $122.63 \pm 4.88^{c}$ & $5.95 \pm 0.76^{b, c, d}$ & $4.04 \pm 0.72^{c, d}$ & $6.87 \pm 0.11^{c}$ & $6.87 \pm 0.11^{\mathrm{a}}$ & $0.98 \pm 0.00^{c}$ & $1.31 \pm 0.01^{\mathrm{c}}$ \\
\hline OIRP & $70.52 \pm 0.80^{\mathrm{d}}$ & $1.94 \pm 0.00^{\mathrm{e}}$ & $4.78 \pm 0.18^{c}$ & $4.70 \pm 0.00^{\mathrm{d}}$ & $2.97 \pm 0.03^{c}$ & $0.32 \pm 0.01^{\mathrm{d}}$ & $0.25 \pm 0.00^{d}$ \\
\hline OIYP & $29.16 \pm 0.07^{\mathrm{a}}$ & $7.88 \pm 0.17^{\mathrm{a}}$ & $8.74 \pm 0.19^{\mathrm{e}}$ & $15.29 \pm 0.02^{\mathrm{e}}$ & $1.83 \pm 0.04^{\mathrm{d}}$ & $1.06 \pm 0.01^{b}$ & $1.48 \pm 0.00^{\mathrm{a}}$ \\
\hline OISP & $47.87 \pm 1.10^{b}$ & $4.53 \pm 0.31^{c}$ & $3.98 \pm 0.21^{\mathrm{d}}$ & $16.24 \pm 0.05^{\mathrm{f}}$ & $3.66 \pm 0.01^{\mathrm{e}}$ & $2.10 \pm 0.01^{\mathrm{e}}$ & $2.24 \pm 0.01^{b}$ \\
\hline OIYF & $164.41 \pm 9.87^{\mathrm{e}}$ & $4.68 \pm 0.37^{c, d}$ & $5.16 \pm 0.16^{c}$ & $0.40 \pm 0.00 \mathrm{~g}$ & $0.19 \pm 0.00^{\mathrm{f}}$ & $0.36 \pm 0.00^{\mathrm{d}}$ & $1.12 \pm 0.00^{\mathrm{e}}$ \\
\hline OIFL & $180.24 \pm 2.20^{\mathrm{e}}$ & $3.78 \pm 0.29^{\mathrm{d}}$ & $0.58 \pm 0.14^{\mathrm{f}}$ & $0.09 \pm 0.00^{\mathrm{h}}$ & $0.04 \pm 0.00^{g}$ & $0.06 \pm 0.00^{f}$ & $0.26 \pm 0.00^{d}$ \\
\hline Ascorbic acid & $4.04 \pm 0.20$ & - & - & - & - & - & - \\
\hline
\end{tabular}

${ }^{*}$ Different letters in the same column are significantly different $(p<0.05)$. DPPH $=2$,2-diphenyl-1-picrylhydrazyl, TPC $=$ total phenolic content, $\mathrm{TFC}=$ total flavonoid content, $\mathrm{B} 0=$ compound $\mathrm{B} 0$ which appeared as a peak at the retention time of 6.00 min analyzed by the same HPLC method, OIRL = orange-red crystals from $O$. indicum seed collected from Lampang province, OIYL = yellow precipitates from O. indicum seed collected from Lampang province, $\mathrm{OISL}=\mathrm{O}$. indicum seed extracts from Lampang province, OIRP $=$ orange-red crystals from $O$. indicum seed collected from Pattani province, OIYP = yellow precipitates from O. indicum seed collected from Pattani province, $\mathrm{OISP}=\mathrm{O}$. indicum seed extracts from Pattani province, $\mathrm{OIYF}=\mathrm{O}$. indicum young fruit extract, $\mathrm{OIFL}=\mathrm{O}$. indicum flower extract.

2.2. Determination of Total Phenolic Content in O. indicum Samples Using the Folin-Ciocalteu Method and Determination of Total Flavonoid Content in O. indicum Samples Using the Aluminium Chloride Method

As shown in Table 1, most O. indicum samples contained high amounts of total phenolic and total flavonoid contents, except the flower extracts which contained a low amount of total flavonoid content $(<1 \mathrm{~g} \% \mathrm{QE})$.

\subsection{Analysis of Flavone Contents in O. indicum Samples by HPLC}

Regarding the system suitability parameters, tailing factors of all three standard compounds were less than 2, theoretical plate numbers were in the range of 10,000 to $90,000 \%$ relative standard deviation (RSD) values of the peak area were less than 2 and the standard deviation (SD) values of the retention times of each peak were less than 1, suggesting the suitability of the analytical method. Figure 1 shows the HPLC chromatograms of $O$. indicum samples.

As shown in Figure 1, HPLC analysis of O. indicum samples showed specific chromatographic fingerprints with the presences of the peaks that corresponded to baicalin, baicalein and chrysin at retention times of 6.17,9.92 and $12.97 \mathrm{~min}$, respectively, according to standard mixture HPLC chromatogram in Figure 2. However, in most O. indicum samples, there was a peak (peak B0) that appeared at the retention time of $6.00 \mathrm{~min}$ before the peak of baicalin, except in the seed extract of $O$. indicum collected from Lampang province (OISL) which did not show the presence of this peak (B0). Moreover, there were other major peaks at retention times of 4.09 and 7.42 min (peak Rt 4 and peak Rt 7, respectively) in most O. indicum samples except in O. indicum flower extract (OIFL) which did not have both peaks and O. indicum young fruit extract (OIYF), which did not have peak Rt 4 . Table 2 summarizes the HPLC retention times, UV spectra, previous reported MS data and chemical structures of six major peaks in O. indicum extracts and fractions. 

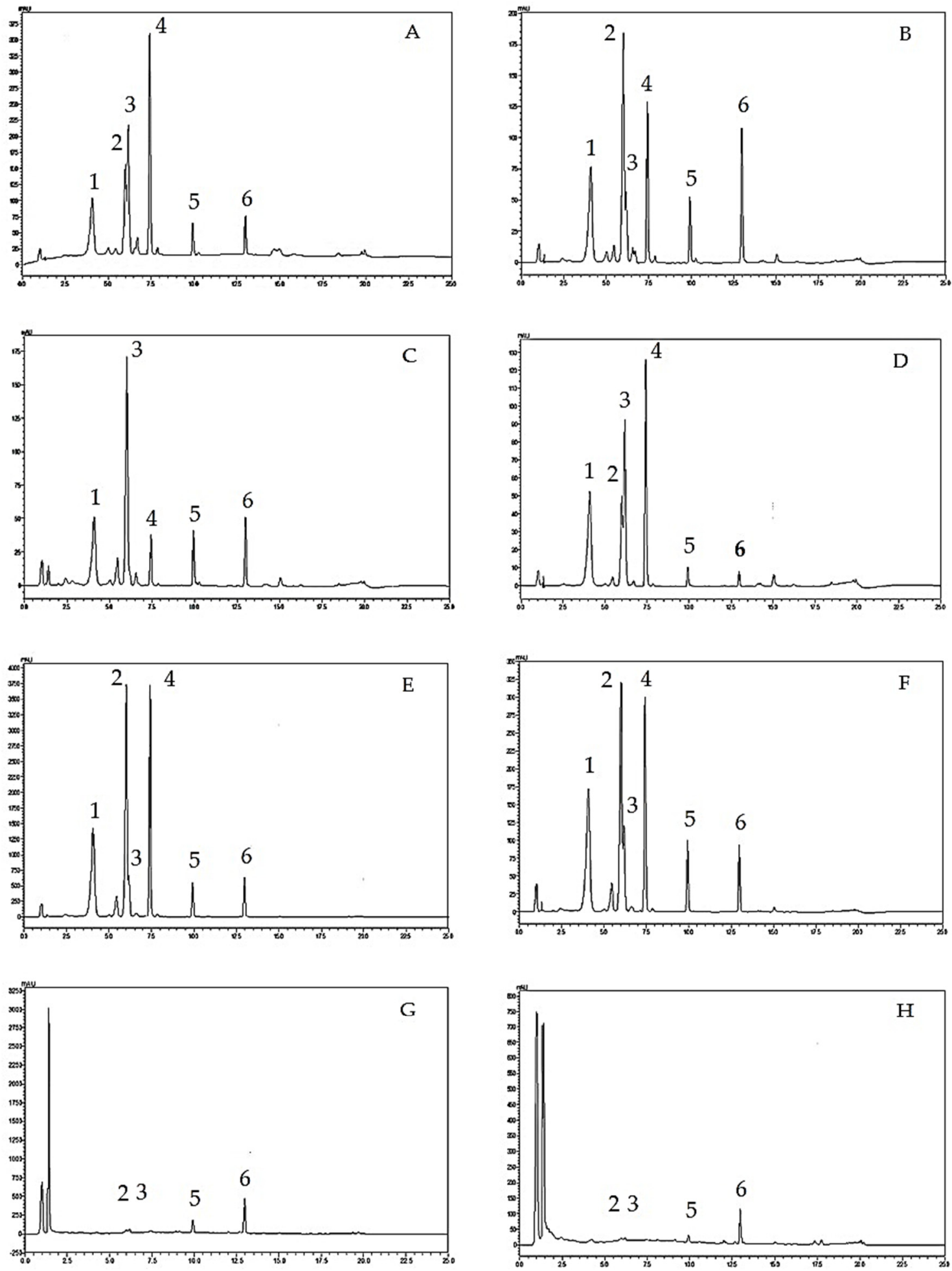

Figure 1. HPLC chromatograms of Oroxylum indicum samples; (A) = OIRL(orange-red crystals from O. indicum seed collected from Lampang province), (B) = OIYL (yellow precipitates from O. indicum seed collected from Lampang province), (C) = OISL (O. indicum seed extracts from Lampang province), (D) (OIRP = orange-red crystals from O. indicum seed collected from Pattani province), (E) = OIYP (yellow precipitates from O. indicum seed collected from Pattani province), $(\mathbf{F})=\operatorname{OISP}(\mathrm{O}$. indicum seed extracts from Pattani province), $(\mathbf{G})=\operatorname{OIYF}(O$. indicum young fruit extract $)$, and $(\mathbf{H})=\mathrm{OIFL}$ (O. indicum flower extract). HPLC peaks; $1=$ compound Rt 4, $2=$ compound B0, $3=$ baicalin, $4=$ compound Rt 7, 5= baicalein, $6=$ chrysin. 


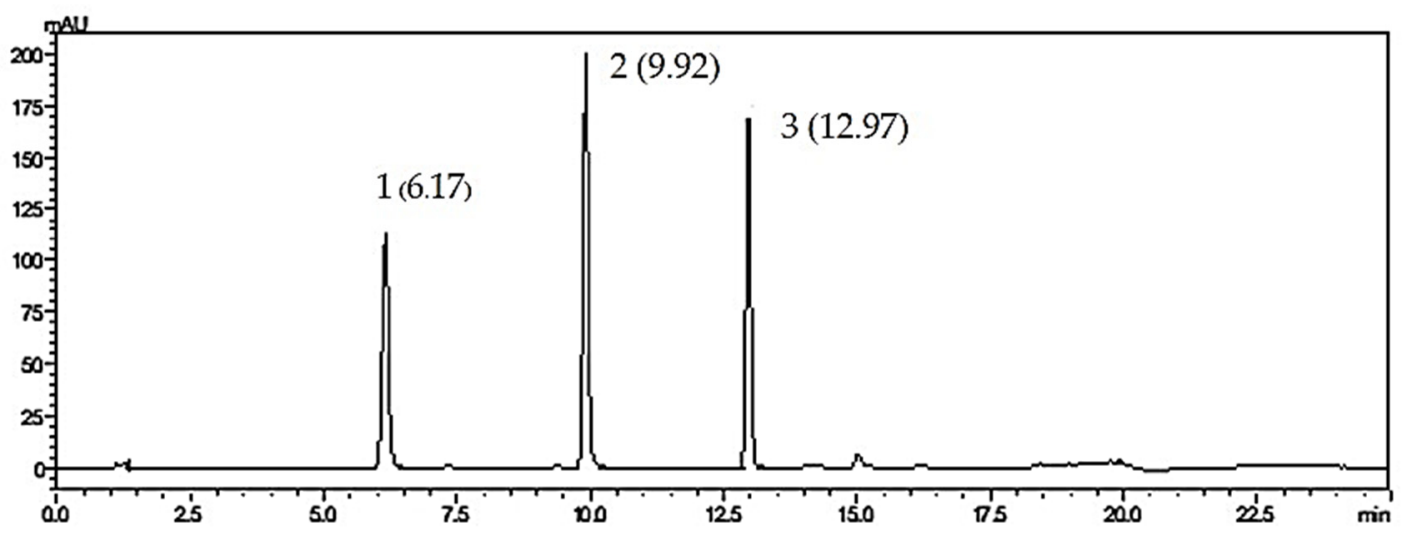

Figure 2. HPLC chromatograms of standard compounds; 1 = baicalin, 2 = baicalein, 3 = chrysin.

Table 2. HPLC retention Times, UV Spectra, Previous Reported MS Data and Chemical Structures of Chemical Compounds in O. indicum Extracts and Fractions.

\begin{tabular}{|c|c|c|c|c|c|}
\hline Peak No. & Rt (min.) & $\begin{array}{l}\text { UV Spectra } \\
\left(\lambda_{\max }, \mathrm{nm}\right)\end{array}$ & $\begin{array}{l}\text { Previous Reported } \\
\text { MS Data }{ }^{\#}(\mathrm{~m} / \mathrm{z})\end{array}$ & Compound & Chemical Structure \\
\hline \multirow{3}{*}{1} & 4.09 & $215,276,315$ & & compound Rt 4 & \\
\hline & & $214.9,277.4,316.6^{\mathrm{d}}$ & $593,269^{b}$ & $\begin{array}{c}\text { oroxin B * } \\
\text { (baicalein-7-O-diglucoside) }\end{array}$ & \\
\hline & 6.00 & $214,276,316$ & & compound B0 & \\
\hline 2 & & $214.5,277,316.6^{d}$ & $\begin{array}{c}431,269,251,241 \\
223,195^{\mathrm{b}}\end{array}$ & $\begin{array}{c}\text { oroxin A * } \\
\text { (baicalein7-O-glucoside) }\end{array}$ & \\
\hline 3 & 6.17 & $214,276,316$ & $269,445,891^{\mathrm{a}}$ & $\begin{array}{c}\text { Baicalin } \\
\text { (baicalein-7-O-glucuronide) }\end{array}$ & \\
\hline \multirow[b]{2}{*}{4} & 7.42 & $217,266,303$ & & compound Rt 7 & \\
\hline & & $267.9,305.9^{\mathrm{d}}$ & $\begin{array}{c}429,253,209 \\
175,113^{\mathrm{b}}\end{array}$ & Chrysin-7-O-glucuronide * & \\
\hline
\end{tabular}


Table 2. Cont.

\begin{tabular}{|c|c|c|c|c|c|}
\hline Peak No. & Rt (min.) & $\begin{array}{l}\text { UV Spectra } \\
\left(\lambda_{\max }, \mathrm{nm}\right)\end{array}$ & $\begin{array}{l}\text { Previous Reported } \\
\text { MS Data }{ }^{\#}(\mathrm{~m} / \mathrm{z})\end{array}$ & Compound & Chemical Structure \\
\hline 5 & 9.92 & $214,273,321$ & $223,251,269^{a}$ & baicalein & \\
\hline 6 & 12.97 & $214,261,311$ & $\begin{array}{c}180,181,209 \\
253,254^{\text {a }}\end{array}$ & chrysin & \\
\hline
\end{tabular}

${ }^{\mathrm{a}}=$ Rojsanga et al., 2017 [24], ${ }^{\mathrm{b}}=$ Peng et al., 2019 [13], ${ }^{\mathrm{c}}=$ Lin and Harnly, 2007 [26], ${ }^{\mathrm{d}}=$ Yuan et al., 2008 [18], ${ }^{*}$ proposed compound, ${ }^{*}$ Mass Spectral Data.

Quantitative analysis of the three flavones; baicalin, baicalein and chrysin, by HPLC in the O. indicum samples showed that OISL and OIRL contained the highest amounts of baicalin ( $>6 \mathrm{~g} \%$ in the extracts). Other O. indicum samples from the seeds contained moderate amounts of baicalin while the extracts from the young fruits and the flowers of $O$. indicum contained low amounts of this compound ( $<1 \mathrm{~g} \%$ in the extracts). Baicalein and chrysin were found in lower amounts than baicalin in all O. indicum samples (not more than $3 \mathrm{~g} \%$ in the extracts). The total amounts of baicalin and compound B0 (calculated as baicalin) are also shown in Table 1. OISP, OIYP and OIRL showed high cumulative amounts of baicalin and compound B0 ( $>10 \mathrm{~g} \%$ in the extracts) which correlate to their high antioxidant activities. The results suggest that compound B0 should be responsible for the antioxidant activities of the $O$. indicum samples.

\subsection{Determination of In Vitro Antibacterial Activity of O. indicum Samples Using Disc Diffusion Assay}

Oroxylum indicum seed samples collected from Lampang province including orangered crystals, yellow precipitate and extract (OIRL, OIYL and OISL, respectively) and young fruit extract (OIYF) were determined for antibacterial effects against clinical isolated zoonotic bacteria including S. intermedius, S. suis, P. Aeruginosa, and $\beta$-hemolytic E. coli and S. aureus using the disc diffusion method. As shown in Table 3, both seed extracts (OISL) and young fruit extracts (OIYF) contained low amounts of flavone contents but still promoted antibacterial effects against all of the tested bacteria. Orange-red crystals of $O$. indicum from Lampang province (OIRL) showed strong inhibitory effects on $\beta$-hemolytic $E$. coli and a weak inhibitory effect against $S$. intermedius while the yellow precipitate (OIYL) showed no inhibitory effect against all of the tested bacteria. Since OIYF showed a reliable antibacterial activity to every pathogen, and the young fruit of $O$. indicum is a part of the plant considered appropriate in terms of accessibility and practicality for quality control, it was the first priority among extracts submitting for determination of half-maximal inhibitory concentrations $\left(\mathrm{IC}_{50}\right)$ and minimum inhibitory concentrations (MICs). 
Table 3. Antibacterial Effects Against Clinical Isolated Zoonotic Bacteria of O. indicum Samples.

\begin{tabular}{cccccc}
\hline \multirow{2}{*}{ Sample } & \multicolumn{5}{c}{ Zone of Inhibition at the Concentration of $\mathbf{5 0 ~} \mathbf{~ m g} / \mathbf{m L} \mathbf{( m m )}$} \\
\cline { 2 - 6 } & S. intermedius & S. suis & $\boldsymbol{P}$ aeruginosa & $\boldsymbol{\beta}$-Hemolytic $\boldsymbol{E}$. coli & S. aureus \\
\hline OIRL & $9.50 \pm 0.70$ & 0 & 0 & $20.00 \pm 0.00$ & 0 \\
OIYL & 0 & 0 & 0 & 0 & 0 \\
OISL & $17.00 \pm 2.78$ & $11.83 \pm 2.25$ & $11.50 \pm 0.70$ & $15.75 \pm 1.77$ & $10.50 \pm 1.32$ \\
OIYF & $12.83 \pm 0.76$ & $10.42 \pm 2.13$ & $10.25 \pm 1.06$ & $13.00 \pm 1.41$ & $11.33 \pm 1.26$ \\
AMC30 & $31.00 \pm 1.73$ & $25.60 \pm 0.96$ & 0 & $22.00 \pm 1.73$ & $25.60 \pm 0.96$ \\
DO30 & $15.67 \pm 2.31$ & $16.83 \pm 1.29$ & $14.25 \pm 0.35$ & $25.00 \pm 1.41$ & $16.83 \pm 1.29$ \\
SXT25 & 0 & 0 & $14.50 \pm 0.70$ & $25.67 \pm 0.58$ & 0 \\
\hline
\end{tabular}

OIRL = orange-red crystals from $O$. indicum seed collected from Lampang province, OIYL = yellow precipitates from $O$. indicum seed collected from Lampang province, OISL $=$ O. indicum seed extracts from Lampang province, and OIYF $=O$. indicum young fruit extract. AMC 30 = Amoxicillin/clavulanic acid $30 \mu \mathrm{g}$, DO 30 = doxycycline $30 \mu \mathrm{g}$ and SXT 25 = sulfamethoxazole-trimethoprim $25 \mu \mathrm{g}$.

\subsection{Determination of the Half-Maximal Inhibitory Concentrations $\left(\mathrm{IC}_{50}\right)$ and the Minimum Inhibitory Concentrations (MICs)}

The half-maximal inhibitory concentrations $\left(\mathrm{IC}_{50}\right)$ and the minimum inhibitory concentrations (MICs) of OIYF to each pathogenic bacterium were determined. The young fruit extract of $O$. indicum (OIYF) showed effectiveness in inhibiting the five clinically important bacteria. In gram positive bacteria, S. aureus, S. intermedius, and S. suis, they were subdued by OIYF more profoundly compared to clinically important gram negative bacteria, $\beta$-hemolytic E. coli, and P. aeruginosa. OIYF showed the lowest $\mathrm{IC}_{50}$ and MIC values against $S$. aureus at $0.40 \pm 0.00 \mathrm{mg} / \mathrm{mL}$ and $4.67 \pm 0.04 \mathrm{mg} / \mathrm{mL}$, respectively. Corresponding results were found in $S$. intermedius and $S$. suis at $\mathrm{IC}_{50}$ and $\mathrm{MIC}$ values $0.81 \pm 0.04 \mathrm{mg} / \mathrm{mL}$ and $5.17 \pm 1.23 \mathrm{mg} / \mathrm{mL}$ in $S$. intermedius, $0.96 \pm 0.46 \mathrm{mg} / \mathrm{mL}$ and $10.54 \pm 1.00 \mathrm{mg} / \mathrm{mL}$ in S. suis accordingly. The results suggested similar mechanisms of antibacterial activity of OIYF toward these three zoonotic bacteria, or at least one stated association of the chemicalpathogen interactions involved in particular characteristics of gram positive bacterial cell wall and cell membrane dysfunction. This may be attributed to either direct damage to the cytoplasmic membrane or indirect damage effected through autolysis/weakening of the cell wall and consequent osmotic lysis. Interestingly, inhibitory activity of the extract to $\beta$-hemolytic E. coli and P. aeruginosa were shown to be 16.35 - and 8.93 -fold of IC $_{50}$ values and 4- and 9.8-fold of MIC values compared to $S$. Aureus, suggesting various mechanisms of action in the antibacterial activities of the extract [27]. Table 4 showed minimum inhibitory concentrations (MICs) and half-maximal inhibitory concentration $\left(\mathrm{IC}_{50}\right)$ of $\mathrm{O}$. indicum young fruit extract (OIYF) against clinical isolated zoonotic bacteria. Chemico-pathogen interactions and the significance of the $O$. indicum flavone-contained extracts attributed to bacterial cytoplasmic membrane integrity and membrane alteration were then determined using scanning electron microscopy.

Table 4. Minimum Inhibitory Concentrations (MICs) and Half-Maximal Inhibitory Concentration $\left(\mathrm{IC}_{50}\right)$ of O. indicum Young Fruit Extract (OIYF) Against Clinical Isolated Zoonotic Bacteria.

\begin{tabular}{ccc}
\hline Bacterial Species & IC $_{\mathbf{5 0}}(\mathbf{m g} / \mathbf{m L})$ & MIC $(\mathbf{m g} / \mathbf{m L})$ \\
\hline S. intermedius & $0.81 \pm 0.04$ & $5.17 \pm 1.23$ \\
S. suis & $0.96 \pm 0.46$ & $10.54 \pm 1.00$ \\
P. aeruginosa & $3.59 \pm 1.01$ & $46.72 \pm 1.94$ \\
B-hemolytic E. coli & $6.57 \pm 0.69$ & $19.11 \pm 0.62$ \\
S. aureus & $0.40 \pm 0.00$ & $4.67 \pm 0.04$ \\
\hline
\end{tabular}

2.6. Evaluation of Antibacterial Mechanism of Action of O. indicum by Scanning Electron Microscopic Technique

After the young fruit extract of $O$. indicum (OIFY) at a concentration of $5 \mathrm{mg} / \mu \mathrm{L}$ was incubated with $3 \times 10^{6} \mathrm{CFU} /$ well in MHB of each clinical isolated bacteria; S. intermedius, S. suis, $\beta$-hemolytic E. coli, P. aeruginosa and $S$. aureus at $37^{\circ} \mathrm{C}$ for $15 \mathrm{~h}$, a significant 
morphological damage and agglutination of the cells treated with OIFY was clearly shown (Figure 3A2-E2) compared to the untreated cells (Figure 3A1-E1). The pathogens had decreased in size and changed in shape, seen in cell wrinkle and shrinkage. They also created signs of cellular membrane disruption, leakage of cellular contents, cell fusion and agglutination. The results suggest that the mechanisms of action of $O$. indicum young fruit extract on these clinically important pathogens could be on the bacterial cell membrane, extracellular proteins or other regulatory protein-induced cell membrane disruption and cell lysis.

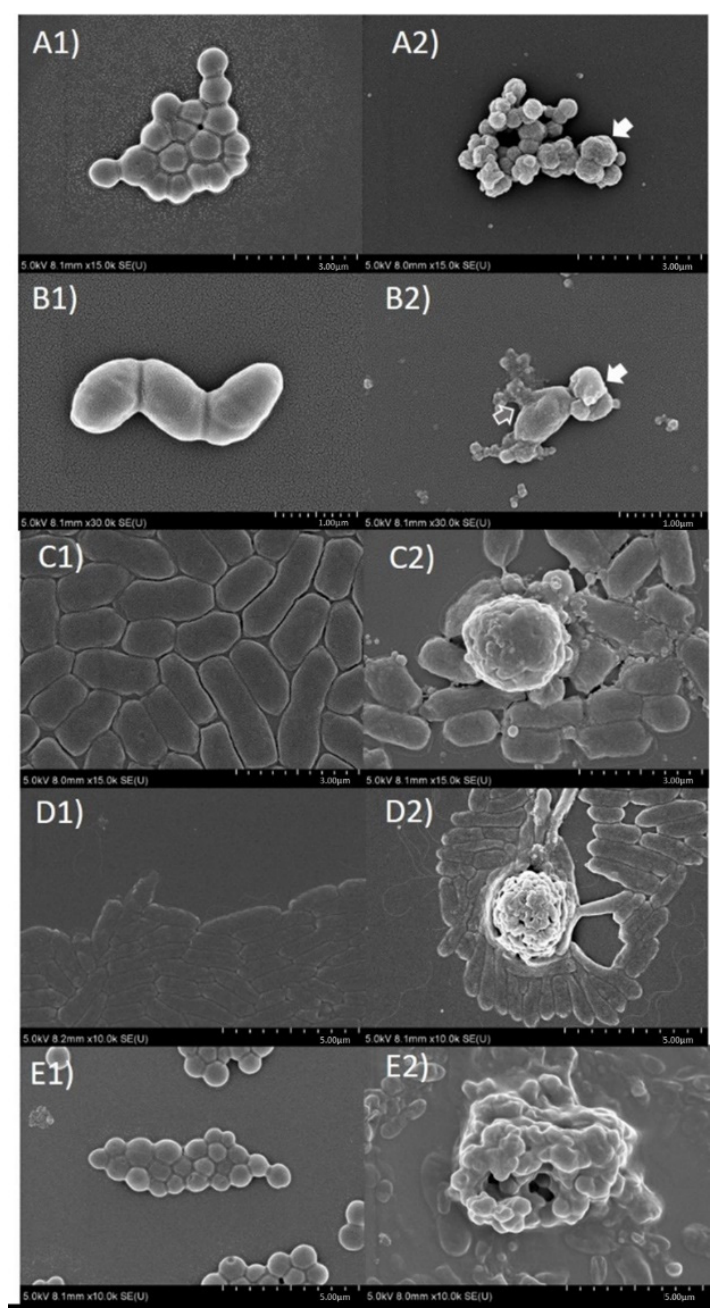

Figure 3. Scanning electron microscopic micrograph (SEM) of clinically isolated bacteria after treatment with young fruit extract of $O$. indicum (OIFY) at the concentration of $5 \mathrm{mg} / \mathrm{mL}$ (A1) = Staphylococcus intermedius without OIYF treatment, (A2) = Staphylococcus intermedius with OIFY treatment; (B1) = Streptococcus suis without OIYF treatment, (B2) = Streptococcus suis with OIYF treatment, $(\mathbf{C 1})=\beta$-hemolytic Escherichia coli without OIYF treatment, $(\mathbf{C} 2)=\beta$-hemolytic Escherichia coli with OIYF treatment, (D1) = Pseudomonas aeruginosa without OIYF treatment, (D2) = Pseudomonas aeruginosa with OIYF treatment, (E1) = Staphylococcus aureus without OIYF treatment, (E2) = Staphylococcus aureus with OIYF treatment. (A2,B2) White arrows = cell fusion, (B2) Grey arrow = cellular content leakage.

\subsection{Evaluation of Correlations between Antioxidant and Antibacterial Activities and Phytochemical Contents}

Table 5 shows the correlation between the antioxidant and antibacterial activities and the total phenolic contents, total flavonoid contents and HPLC peak areas of flavones in O. indicum samples including baicalin, baicalein, chrysin and also the HPLC peak areas of 
three unidentified compounds; compound at retention time $=6.00 \mathrm{~min}$ (compound B0), compound at retention time $=4.09 \mathrm{~min}$ (compound Rt 4 ) and compound at retention time $7.42 \mathrm{~min}$ (compound Rt 7). Total phenolic and total flavonoid contents showed high correlations with the inhibitory effects against $S$. suis, P. aeruginosa and S. aureus (R values $>0.8$ ) while only the total flavonoid content showed a high correlation with the inhibitory effect against $S$. intermedius $(\mathrm{R}$ value $=0.925)$. Both total phenolic and total flavonoid contents showed a low correlation with the inhibitory effects against $\beta$-hemolytic E. coli. Peak areas of all three unidentified compounds, compound B0, compound Rt 4 and compound Rt 7 and total peak area of compound B0 and baicalin showed high correlations with inhibitory effects against $S$. suis, P. aeruginosa and S. aureus while only the peak area of compound B0 showed a high correlation with inhibitory effects against $S$. intermedius. The only peak area of baicalin showed a high correlation with inhibitory effects against $\beta$-hemolytic $E$. coli while other peak areas of other compounds in $O$. indicum samples showed low or moderate correlations. The results suggest that most tested bacteria except $\beta$-hemolytic $E$. coli are susceptible to most $O$. indicum samples, due to the effects of their chemical constituents. Peak areas of baicalein and chrysin exhibited a low to moderate correlation with inhibitory effects against all of the selected clinical isolated bacteria. Regarding the antioxidant activities, total phenolic and total flavonoid contents and the peak area of baicalin exhibited high correlations with the DPPH scavenging effects, peak areas of baicalein, compound B0, compound Rt 4 and compound Rt 7 also exhibited moderate correlations while the chrysin content exhibited a low correlation.

Table 5. The R Values (Correlation Coefficients) between the Antioxidant $\left(1 / \mathrm{EC}_{50}, \mu \mathrm{g} / \mathrm{mL}\right)$ and Antibacterial Activities (Zone of Inhibition, mm) and Total Phenolic Contents (g\% GAE), Total Flavonoid Contents ( $\mathrm{g} \%$ QE) and the Peak Areas of flavones in O. indicum samples.

\begin{tabular}{ccccccc}
\hline & $\begin{array}{c}\text { 1/DPPH (2,2-Diphenyl- } \\
\text { 1-Picrylhydrazyl) }\end{array}$ & S. intermedius & S. suis & P. aeruginosa & $\beta$-Hemolytic E.coli & S. aureus \\
\hline TPC & 0.698 & 0.441 & 0.838 & 0.842 & 0.116 \\
TFC & 0.689 & 0.925 & 0.920 & 0.917 & 0.505 & 0.890 \\
B1 & 0.665 & 0.545 & 0.055 & 0.049 & 0.774 & 0.862 \\
B2 & 0.455 & 0.208 & 0.439 & 0.446 & 0.022 & 0.043 \\
C & 0.196 & 0.164 & 0.433 & 0.441 & 0.066 & 0.557 \\
B1 + B2 + C & 0.593 & 0.023 & 0.064 & 0.072 & 0.171 & 0.203 \\
B1 + B0 & 0.573 & 0.406 & 0.827 & 0.830 & 0.516 & 0.920 \\
B0 & 0.556 & 0.940 & 0.957 & 0.956 & 0.063 & 0.863 \\
Rt 4 & 0.574 & 0.488 & 0.785 & 0.790 & 0.344 & 0.793 \\
Rt 7 & 0.598 & 0.316 & 0.790 & 0.791 & \\
\hline
\end{tabular}

$\mathrm{TPC}=$ total phenolic content $(\mathrm{g} \% \mathrm{GAE}), \mathrm{TFC}=$ total flavonoid content $(\mathrm{g} \% \mathrm{QE}), \mathrm{B} 1=$ baicalin content $(\mathrm{g} \%), \mathrm{B} 2=$ baicalein content $(\mathrm{g} \%)$, $\mathrm{C}=$ chrysin content $(\mathrm{g} \%), \mathrm{B} 0=$ compound at retention time of $6.00 \mathrm{~min}, \mathrm{Rt} 4=$ compound at retention time of $4.09 \mathrm{~min}, \mathrm{Rt} 7=$ compound at retention time of $7.42 \mathrm{~min}$.

\section{Discussion}

O. indicum seed, young fruit and flower extracts, orange-red crystals and yellow precipitate promoted in vitro DPPH scavenging effects and antibacterial activities on clinical isolated bacteria including S. intermedius, S. suis, P. aeruginosa, $\beta$-hemolytic E. coli and $S$. aureus. Most $O$. indicum samples contained high amounts of total phenolic and total flavonoid contents together with the presence of three flavones, baicalin, baicalein and chrysin and another three unidentified compounds, compound B0, compound Rt 4 and compound Rt 7 . The generation of orange-red crystals and yellow precipitate could be found from both O. indicum seeds collected in Lampang province in 2019 and from Pattani province in 2016. Orange-red crystals from $O$. indicum seeds collected from both provinces contained very similar amounts of baicalin content as the seed extracts from the same sources while yellow precipitates contained lower amounts of baicalin. Orange-red crystals and the seed extract from O. indicum seeds collected in Lampang province (OIRL and OISL, respectively) contained higher baicalin contents than the orange-red crystal and the seed extract from O. indicum seeds collected from Pattani province (OIRP and OISP, respectively). 
These results suggest that the collection locations and the storage time of the plant material could affect the phytochemical contents of O. indicum seeds. Young fruit extract (OIYF), which contained low amounts of flavone contents, still promoted antibacterial effects against tested bacteria suggesting that there could be other phytochemicals responsible for these antibacterial effects. The possible process of generation of these orange-red crystals and yellow precipitates could be the saturation of flavones in the extraction solution during the evaporation process resulting in the precipitation of enriched flavone mixtures in different forms. However, factors related to their generation or to the specific ratios of their chemical composition are still unclear.

Total phenolic and total flavonoid contents and peak areas of baicalin exhibited a significant correlation to antioxidant activity; peak areas of baicalein, compound B0, compound Rt 4 and compound Rt 7 showed moderate correlations while chrysin content showed a low correlation. The results correspond to our previous studies, which revealed that total phenolic and total flavonoid contents could be responsible for the antioxidant activities of $O$. indicum extracts while baicalin and baicalein were found to be the active compounds [24]. Total phenolic, total flavonoid and peak areas of compound B0, compound Rt 4 and compound Rt 7 showed high correlations with the inhibitory effects against S. suis, P. aeruginosa and S. aureus. Total flavonoid content and peak area of compound B0 exhibited a high correlation with the inhibitory effects against $S$. intermedius. Only the peak area of baicalin exhibited a high correlation with the inhibitory effect against $\beta$-hemolytic E. coli.

In this study, the seed extract from O. indicum collected from Lampang province and the young fruit extract promoted in vitro antibacterial effects on all tested bacteria. The results correspond to our previous study which reported that the fruit ethanol extract of O. indicum promoted high inhibitory effects on these bacteria [12]. Orange-red crystal from Lampang province was found to exhibit high inhibitory effects on $\beta$-hemolytic E. coli, which could be related to the high amount of baicalin content that was previously reported to promote a significant inhibitory effect on this bacterium [12]. Our previous report suggested that there could be a specific ratio or range of active flavonoids in O. indicum extracts necessary to promote a strong antibacterial effect or there could be other active constituents that promote antibacterial activity in O. indicum extracts [12]. These active compounds could be compound B0, compound Rt 4 and compound Rt 7 as their peak area was highly correlated to the antibacterial effect in this study. The previous report suggested that compound B0 could be orexin A while compound Rt 4 could be orexin $\mathrm{B}$ and compound Rt 7 could be chrysin-7-O-glucuronide [13]. Orexin A was reported to promote antioxidant, anticancer, antibacterial and antidiabetic effects [28,29], while oroxin B showed anti-lymphoma effect [30], inhibitory effects to the hemolytic activity [31] of $\alpha$-hemolysin and anticancer effects [32,33]. Chrysin-7-O-glucuronide also exhibited antioxidant activity [34]. Our study suggests that these compounds could be responsible for the antioxidant and antibacterial activities of the O. indicum samples.

However, the conditions of orange-red crystal and yellow precipitate generations are still unclear. There could be various possible phenomena including the co-crystallization of the compositional flavones in the evaporating extract solution in different ratios or the forming rates resulting in the precipitation of a yellow precipitate or the generation of orange-red crystals. Co-crystals have been reported as multiple component crystals in which all components are solid under ambient conditions whilst in their pure form [35]. One report suggested the co-crystallization of naringenin with 27 co-formers, which led to the formation of a salt and four co-crystals [36]. Several new forms of quercetin in the form of solvates and co-crystals were synthesized [37]. Solvated quercetin was generated by quercetin crystallized with two water molecules that participate in an extended hydrogen bonding network while the quercetin dimer was formed by the hydroxyl $(\mathrm{OH})$ and the adjacent carbonyl moiety hydrogen bonding [37]. In this report, two different cocrystal quercetins; co-crystals I and II with caffeine and iso-nicotinamide could be formed during the slow evaporation [37]. Nicotinamide and picolinic acid co-crystals of quercetin 
were also reported [38]. The properties of the solid binary system between quercetin and nicotinamide including the melting point, solubility and physical morphology were reported to be different from the physical mixture of quercetin-nicotinamide [39]. These studies suggest that co-crystallization could be occurring between flavonoids and the different molecules that have functional groups which could be forming bonds with them, then altering the properties of the compounds. Therefore, in this study, three major flavones, baicalin, baicalein and chrysin, could be forming co-crystals between themselves or with other molecules in the extract solution during the evaporation process. Another possible phenomenon is crystallization in different hydrated forms. Wogonin, a flavone compound, can be formed as two distinct hydrated crystal forms, yellow block-shaped crystals of wogonin monohydrate and yellow needle-shaped crystals of wogonin sesquihydrate [40]. This report suggested that the formation of wogonin crystals could be affected by the uncertainty in the water content in the atmosphere and also by contamination with the phase of alternate hydrate stoichiometry [40]. These forms of wogonin were found to affect the solubility and bioavailability of this compound in an animal model [41]. The final phenomenon that could affect the precipitation of yellow precipitate and orange-red crystal of $O$. indicum seed extracts is the formation of different polymorphisms of flavonoids. Two crystalline components obtained from the gel filtration chromatographic separation of hexane extract from Melicope ellyrana fruits were found to be different polymorphs of the same flavonoid [42]. These two polymorphs showed significant conformational differences, particularly in the enyloxy side chain, while only one (polymorph A) shows intermolecular hydrogen bonding [42]. Previous reports suggest the possible factors related to the formation of orange-red crystals and yellow precipitates from $O$. indicum seed extracts, which affects their biological activities and physical properties. In this study, the ratios between baicalin and compound $\mathrm{B} 0$ are various in orange-red crystals, yellow precipitates and seed extracts of $O$. indicum from both Lampang and Pattani provinces. In orangered crystals, baicalin contents are moderate to high while the differences between the amounts of baicalin and compound $\mathrm{B} 0$ are not high. In yellow precipitate, baicalin contents are always low while the amounts of compound B0 are high. In seed extracts, the amount of baicalin is moderate to high while compound B0 could be found in a high amount or could not be found. Comparison between these extracts and enriched fractions suggests that both baicalin and compound B0 play an important role in DPPH scavenging effects, while baicalin is mainly responsible for antibacterial effects, and a significant ratio between baicalin and B0 in the compounds has been observed. Further study should be conducted.

As for the mechanism of antibacterial activity, it was found that $O$. indicum young fruit extract caused the changes in bacterial cellular morphology and increase in cell lysis of the tested pathogens, S. intermedius, S. suis, $\beta$-hemolytic E. coli, P. aeruginosa and $S$. Aureus, suggesting the action on the integrity and function of the cell membrane or extracellular proteins, resulting in the disruption of bacterial cell wall/membrane and in destruction of the bacterial cells. The extract also caused the abnormal aggregations in some bacteria including S. intermedius, S. suis and S. aureus. This is the first display of the mechanism of action of $O$. indicum young fruit extract against these important pathogens that could act via cell membrane structure loss of integrity and cell membrane function alteration. Some phytochemicals including phenolics and flavonoids, mainly flavones, alkaloids, terpenes and fatty acids, have been found in various parts of $O$. indicum [3-10,15-18]. These compounds could act together by different mechanisms of action to promote antibacterial effects. Two major mechanisms of interaction of flavonoids with the lipid bilayer of microorganisms were previously reported; the partition of the non-polar compounds in the hydrophobic interior of the membrane, and the formation of hydrogen bonds between the hydrophilic flavonoids and the polar head groups of lipids at the membrane interface [43]. Moreover, nonspecific interactions of flavonoids with phospholipids can induce structural changes of the membrane such as thickness and fluctuations which indirectly modulate the function of membrane proteins, as well as influence the pharmacological properties of flavonoids themselves [44]. Some flavones 
including acacetin and apigenin were reported to cause destabilization of the membrane structure by disordering and disorientation of the membrane lipids and induced leakage from the vesicle [45]. There are studies suggesting that the differences in the number and distribution of hydroxyl groups, the polymerization degree, and the presence of a methoxy groups in the $\mathrm{C}$ ring affect the type of interactions between different flavonoids and lipid bilayers [46]. There are controversial suggestions about the polarity of flavonoids and their effects on membrane disruption, including a suggestion that flavonoids lacking hydroxyl groups on their $\mathrm{B}$ rings are more active against microbial membranes than those with the hydroxyl groups [47], while other studies suggested that lipophilic flavonoids which are highly hydroxylated can be more disruptive to membrane structure [27,48-50]. Another report states that flavonoids cause bacterial aggregation by their partial lysis, which leads to membrane fusion, and consequently reduces the active nutrient uptake via a smaller membrane area [27]. Another suggests that flavones such as 6-amino-flavone, 6-hydroxy-flavone, apigenin and chrysin had inhibitory effects on E. coli O157:H7 biofilm formation [51]. Some flavones including 5,6,7,4',5'-penta-hydroxy-flavone, and 5-hydroxy$4^{\prime}, 7$-dimethoxyflavone were reported to downregulate the malonyl CoA-acyl carrier protein trans-acylase fabD (MCATs) that regulates bacterial-type II fatty acid synthase (FAS-II) which related to inhibition of cell envelope synthesis [52]. Baicalein induced the damage of peptidoglycan, an essential component of the bacterial cell wall [53], while chrysin showed inhibitory effect on DNA gyrase from E. coli [54]. A molecular docking study suggested that flavonoids inhibit the DNA supercoiling by competitively interacting with the ATP binding site of the DNA gyrase B subunit (GyrB) [55,56]. Flavones and flavonols were previously suggested as pharmacophores with nucleic acid binding capacity, especially by helicase inhibition [27]. A flavone luteolin inhibited the replicative helicases such as the DnaB and RecBCD helicase/nuclease of E. coli [57]. Baicalein was also reported as one of the most effective inhibitors of E. coli F1FO ATPase [58]. Moreover, flavonoids have been proposed as resistance modifying agents (RMAs) which could promote synergy and additive effects with antibiotics by inhibition of efflux pumps or antibiotic degrading enzymes and membrane permeabilization [59]. Baicalein has been reported to promote synergistic effects with tetracycline against methicillin-resistant Staphylococcus aureus (MRSA) [53], and with penicillin and amoxicillin against MRSA and penicillinase-producing S. aureus (PPSA), respectively [60] and with cloxacillin against $S$. aureus DMST 20,651 [61]. Baicalein at the concentration of $64 \mu \mathrm{g} / \mathrm{mL}$ acted as efflux pump inhibitors against Mycobacterium smegmatis and Candida albicans [62,63]. At the concentration of $16 \mu \mathrm{g} / \mathrm{mL}$, it could also reverse the ciprofloxacin resistance of MRSA by inhibition of NorA efflux pump [64]. Previous studies suggest that baicalein and chrysin, two of the major flavones in $O$. indicum along with other phenolics and flavonoids, could promote different mechanisms of action to inhibit bacteria growth. From our study, baicalin and compound B0 which has been proposed as oroxin A showed high correlation in antibacterial effects with most tested bacteria. The major mechanism of action should be the formation of hydrogen bonds between the hydrophilic parts of flavonoids and the polar head groups of lipids at the membrane interface so that bacterial membrane depolarization and membrane potential alteration can take place [65], though the novel mechanism of bacterial virulence protein inhibition compromising bacterial transmembrane heptameric channels, causing cell death and the lipophilicity of the flavone components, have been discussed $[31,66]$. The significance of the ratio between baicalin and compound B0 contents should be noted. OIYL, which showed significant difference between baicalin and compound B0 contents, promoted no antibacterial effect while OIYF, which contained lower amounts of both baicalin and compound B0 contents, exhibited decent antibacterial effects. The antibacterial effects of OIYF could be due to the suitable ratio between baicalin and compound B0 contents. Total flavonoid and total phenolic contents also showed high correlation with antibacterial effects, which could be due to the multi-targeting effects of various flavonoids and phenolics in O. indicum. For DPPH scavenging effects, it was clear that the antioxidant effects come from the proton donating abilities of the phytochemicals in O. Indicum. Therefore, the amounts of total 
phenolic, total flavonoid and compounds with proton donating functional groups, such as hydroxyl groups, play an important role in the antioxidant effects. Further study of the mechanism of action of $O$. indicum should be conducted in the future.

\section{Materials and Methods}

\subsection{Chemicals}

Deionized water was obtained by using a water purification system from Thermo Scientific Co. (Waltham, MA, USA). Standard baicalin and chrysin, at a pharmaceutical grade, were purchased from TRC (North York, ON, Canada). Acetonitrile, ascorbic acid, baicalein, DPPH and quercetin at an analytical reference grade, were purchased from Sigma-Aldrich (St. Louis, MO, USA). Aluminum chloride, Folin-Ciocalteu reagent and phosphoric acid were purchased from Merck (Darmstadt, Germany). Gallic acid at an analytical reference grade, was purchased from TOKYO chemical industry Co., Ltd. (Tokyo, Japan). Sodium carbonate was purchased from Ajax Finechem Pty. Ltd. (Sydney, Australia).

\subsection{Plant Materials}

The mature seeds of $O$. indicum were collected from Lampang province in 2019 and from Pattani province in 2016. The fresh young fruits of O. indicum were collected from Nakhon Pathom and Chiang Rai provinces in 2019 while the flowers were collected from Chiang Rai province in 2019. Plant samples were identified by Associate Prof. Pongtip Sithisarn. Plant samples were cleaned and dried in a hot air oven (Memmert, Schwabach, Germany) at $60^{\circ} \mathrm{C}$, then ground using an electric milling machine (Ika-Werke, Staufen, Germany) (20 mesh sieve).

\subsection{Plant Extract Preparations}

Each sample of $O$. indicum from different plant parts was separately extracted by maceration using 95\% ethanol (plant:solvent ratio 1:20 w/v). Each powdered plant sample was separately macerated with $95 \%$ ethanol using an electric flask shaker (Wisd Laboratory Instruments, Wertheim, Germany) for $6 \mathrm{~h}$. The extraction solution was filtered after it was stored for $12 \mathrm{~h}$. Each extraction process was repeated three times. The extraction solutions were then combined, filtered, and evaporated using a water bath to yield the dried extracts. Both young fruit and flower extracts (OIYF and OIFL, respectively) were obtained. The solutions of seed extract of $O$. indicum from Lampang and Pattani provinces were then brought by the separation process to the yellow precipitate and the orange-red crystals.

\subsection{Separation of Yellow Precipitate and Orange-Red Crystal from the Seed Extracts of O. indicum}

During the evaporation of both extract solutions of $O$. indicum seeds, collected from Lampang and Pattani provinces using a rotary evaporator, there was precipitation of a yellow precipitate. This precipitate was separated and collected (OIYL and OIYP for the yellow precipitate from $O$. indicum seeds collected from Lampang and Pattani provinces, respectively). Some parts of this yellow precipitate were then turned into orange-red crystals after they were dried, so they could be separated into OIRL and OIRP for the orange-red crystals from $O$. indicum seeds collected from Lampang and Pattani provinces, respectively. The rest of the extract solutions from each type of $O$. indicum seeds were then dried and a semisolid dark green extract was obtained from the O. indicum seeds from Lampang and Pattani provinces (OISL and OISP, respectively).

\subsection{Determination of In Vitro Antioxidant Activity of O. indicum Samples Using DPPH Scavenging Method}

The 2,2-diphenyl-1-picrylhydrazyl (DPPH) was dissolved in methanol to prepare the DPPH solution at a concentration of $207 \mu \mathrm{M}$. The DPPH solution $(100 \mu \mathrm{L})$ was added to each O. indicum sample solution at various concentrations ranging from 5-640 $\mu \mathrm{g} / \mathrm{mL}$ at the same volume $(100 \mu \mathrm{L})$. The mixture was mixed and kept in the dark for $15 \mathrm{~min}$. The absorbance of each reaction solution was determined at a wavelength of $515 \mathrm{~nm}$ using 
a micro-plate reader. The percentage of inhibition for each reaction was then calculated, and $\mathrm{EC}_{50}$ values $(\mu \mathrm{g} / \mathrm{mL})$ were calculated from the linear equation from the curve between the percentage of inhibition and the solution's concentration. Each experiment was conducted in triplicate. The $\mathrm{EC}_{50}$ value of each sample was expressed as the mean $\pm \mathrm{SD}$. The assays were performed as previously described [24].

\subsection{Determination of Total Phenolic Content in O. indicum Samples Using the Folin-Ciocalteu Method}

The Folin-Ciocalteu assay was carried out according to the method previously described [24] with gallic acid as the standard solution. A Folin-Ciocalteu reagent was added to each $O$. indicum sample or standard gallic acid solution, then the solution was kept in the dark at room temperature for $90 \mathrm{~min}$. After that, a 20\% w/v sodium carbonate solution was added to each mixture. The absorbance of the reaction solution was determined at a wavelength of $765 \mathrm{~nm}$ using a micro-plate reader. The total phenolic compound was calculated from the standard curve of gallic acid and was expressed as gallic acid equivalent per $100 \mathrm{~g}$ extract ( $\mathrm{g} \% \mathrm{GAE}$ ). Each experiment was carried out in triplicate. The average total phenolic content and standard deviation were then calculated.

\subsection{Determination of Total Flavonoid Content in O. indicum Samples Using the Aluminium Chloride Method}

An aluminum chloride determination method was employed using quercetin as the standard solution [24]. An aluminum chloride solution (10\% $w / v)$ was added to each $O$. indicum sample or standard quercetin solution. The mixture was kept at room temperature for $30 \mathrm{~min}$. The absorbance of the reaction solution was determined at a wavelength of $415 \mathrm{~nm}$ using a micro-plate reader. The total flavonoid content was calculated from the standard curve of quercetin and was expressed as g quercetin equivalent per $100 \mathrm{~g}$ extract ( $\mathrm{g} \% \mathrm{QE}$ ). Each experiment was carried out in triplicate. The average total flavonoid content and standard deviation were then calculated.

\subsection{Analysis of Flavone Contents in O. indicum Samples by HPLC}

The contents of three flavones in the O. indicum samples were quantitatively analyzed using the validated HPLC method modified from the previous report [12]. A HPLC analysis was performed using a Shimadzu LC-10ADVP system (Shimadzu, Kyoto, Japan) equipped with a diode array detector (DAD) SPD-M10AVP and a column heater (Shimadzu, Kyoto, Japan). An X-terra C18 column $(150 \mathrm{~mm} \times 3.9 \mathrm{~mm}, 5 \mu \mathrm{m}$ particle size) from Waters (Milford, MA, USA) was used. Gradient elution was performed with a water $-0.01 \%$ phosphoric acid (solvent A) and acetonitrile (solvent B) at a constant flow rate of $1.2 \mathrm{~mL} / \mathrm{min}$. Column temperature was $40^{\circ} \mathrm{C}$ with an injection volume of $20 \mu \mathrm{L}$; detection was performed at $285 \mathrm{~nm}$. The system suitability of the analytical method, including the tailing factor, theoretical plate, \%RSD of the peak area and the SD of the retention time, was also investigated.

\subsection{Clinical Isolated Bacterial, Bacterial Culture, and Culture Media}

Clinical isolates of $S$. intermedius, S. suis, P. aeruginosa, $\beta$-hemolytic E. coli and S. aureus were obtained from the Microbiological Laboratory, Veterinary Diagnostic Center, Faculty of Veterinary Medicine, Kasetsart University, Nakhon Pathom, Thailand. The bacteria strains were isolated and characterized using differential bacterial culture and biochemical assays for clinical samples according to the standard method of Baron et al. [66]. S. Suis, P. aeruginosa, $\beta$-hemolytic E. coli, and $S$. aureus were maintained in Microbank Cryovials and kept at $-80{ }^{\circ} \mathrm{C}$. S. intermedius was maintained in skimmed milk at $-40{ }^{\circ} \mathrm{C}$ until use. Prior to any particular testing, each bacterial strain was maintained on a blood agar plate and incubated for $18-24 \mathrm{~h}$ at $37^{\circ} \mathrm{C}$. Blood agar was obtained from Veterinary Diagnostic Center, Faculty of Veterinary Medicine, Kasetsart University. Mueller-Hinton agar and MuellerHinton broth were purchased from Oxoid, Thermofisher Inc. (St.Louis, MO, USA). 
4.10. Determination of In Vitro Antibacterial Activity of O. indicum Samples Using Disc Diffusion Susceptibility Test

Disc diffusion method was used for antibacterial activity of $O$. indicum extracts from different parts of the plants and the location collected as described earlier: orange-red crystal, yellow precipitates from fruits and the young fruit extract, according to Kirby-Bauer disc diffusion method and CLSI $[67,68]$. Five clinically important pathogenic bacteria were examined; S. intermedius, S. suis, P. aeruginosa, $\beta$-hemolytic E. coli, and S. aureus. A stock solution of each $O$. indicum extract in DMSO was prepared to produce a final concentration of $200 \mathrm{mg} / \mathrm{mL}$. The stock solution was then diluted to concentrations of 3.125, 6.25, 12.5, 25,50 and $100 \mathrm{mg} / \mathrm{mL}$. Twenty microliters of each dilution was impregnated into sterile, blank discs 6-mm in diameter. After the extract was spotted, the discs were allowed to dry to ensure precise impregnation. Twenty microliters of DMSO was used as negative control. All fully dried discs were applied on the corresponding bacterial lawn. Mueller-Hinton agar (S. intermedius, P. aeruginosa, $\beta$-hemolytic E. coli, and S. aureus) or blood agar (S. Suis) was used. The density of the bacterial culture used in lawning was adjusted to 0.5 McFarland standard in Mueller-Hinton broth using a turbidimeter (Biosan, Riga, Latvia). The positive controls were standard antibiotic discs, amoxicillin/clavulanic acid $30 \mu \mathrm{g}$, doxycycline $30 \mu \mathrm{g}$, and sulfamethoxazole-trimethoprim $25 \mu \mathrm{g}$ (Sigma-Aldrich, St. Louis, MO, USA). The plates were incubated at $37^{\circ} \mathrm{C}$ for $24 \mathrm{~h}$ and the zone of inhibition were examined. All determinations were undertaken in triplicate and the average zone of inhibition was calculated with the standard deviation.

\subsection{Determination of the Half-Maximal Inhibitory Concentrations $\left(I_{50}\right)$ and the Minimum Inhibitory Concentrations (MICS)}

The half-maximal inhibitory concentrations $\left(\mathrm{IC}_{50}\right)$ and the minimum inhibitory concentrations (MICs) of O. indicum young fruit extract (OIYF) for each pathogenic bacterium were determined using the broth microdilution method combined with drop plate technique for bacterial enumeration. Briefly, two-fold serial dilutions of extracts in Mueller-Hinton broth (MHB) at concentrations ranging from $0.731-50 \mathrm{mg} / \mathrm{mL}$ were placed in a clear, untreated, polystyrene 96-well plate. The bacterial inoculum was prepared from a subculture in blood agar incubated for $18-24 \mathrm{~h}$ at $37^{\circ} \mathrm{C}$ before to the test. The bacterial culture was adjusted to $0.5 \mathrm{McF}$ arland standard in MHB using a turbidimeter (Biosan, Riga, Latvia). A diluted bacterial suspension was added into the 96-well plate containing the serially diluted extracts to final $1 \times 10^{6} \mathrm{CFU} / \mathrm{mL}$. The final volume of $200 \mu \mathrm{L}$ suspension per well was set. Negative and positive growth controls were performed by adding only MHB and each bacterium with MHB to the wells, respectively. Amoxycillin and doxycycline $4 \mu \mathrm{g} / \mathrm{mL}$ (Sigma-Aldrich, St. Louis, MO, USA) was used as antibiotic control. The plates were incubated at $37^{\circ} \mathrm{C}$ for $18-24 \mathrm{~h}$. Then, an optical density (OD) at $600 \mathrm{~nm}$ was determined using spectrophotometer (SPECTROstar ${ }^{\circledR}$ Nano, BMG LABTECH, Cary, NC, USA) and the concentration at which no bacterial growth comparing to controls was examined, due to the turbidity interfering with the extracts at a certain concentration range. The capability of different extracts to inhibit bacterial growth was confirmed with quantification by drop plate technique for bacterial enumeration.

\subsection{Drop Plate Technique for Bacterial Enumeration (DP)}

After the incubation time was complete, all bacterial suspensions were adjusted to approximately desired $\log 10 \mathrm{CFU} / \mathrm{mL}$ using standard serial 10-fold dilution in $\mathrm{MHB}$, and $20 \mu \mathrm{L}$ were transferred for drop plating on Mueller-Hinton agar (S. intermedius, P. aeruginosa, $\beta$-hemolytic E. coli, and S. aureus) or blood agar (S. Suis). The drops were absorbed to agar in less than half an hour. Then, the plates were incubated at $37^{\circ} \mathrm{C}$ for $18-24 \mathrm{~h}$ and the viable pathogens were enumerated. At least 3 to 30 colonies of the bacteria grew from $10 \mu \mathrm{L}$ of drop and 30 to $300 \mathrm{CFU}$ per $100 \mu \mathrm{L}$ of the bacteria as a confidence technique were chosen for counting [69]. The total count of CFU from at least three drops at the countable dilution were determined and averaged. Finally, the total count was scaled up and the viable 
cell counts were expressed as CFU/mL [70]. The bacterial cell viability, the half-maximal inhibitory concentrations $\left(\mathrm{IC}_{50}\right)$ and the minimum inhibitory concentration (MIC) data were analyzed.

\subsection{Evaluation of Antibacterial Mechanism of Action of O. indicum by Scanning Electron Microscopic Technique}

The Scanning Electron Microcopy (SEM) method was used to observe bacterial cell morphology. Each bacterial culture suspension was adjusted to final concentration of $3 \times 10^{6} \mathrm{CFU} / \mathrm{mL}$ in Mueller-Hinton broth with the O. indicum young fruit extract (OIYF) at a concentration of $5 \mathrm{mg} / \mathrm{mL}$ and without extract (control culture) in parallel. The cell suspensions were incubated at $37^{\circ} \mathrm{C}$ for $15 \mathrm{~h}$ and were harvested for Scanning Electron Microscopy sample preparations. The bacterial cells were washed three times with sterile deionized water at $2000 \times g$ centrifugation for $10 \mathrm{~min}$. The cell pellet was collected and fixed by $10 \%$ paraformaldehyde (Sigma-Aldrich, St. Louis, MO, USA) and 2.5\% glutenaldehyde (Sigma-Aldrich, St. Louis, MO, USA) solution for 30-60 min. The samples were further dehydrated by a serial concentration gradient of 30\%, 50\%, 70\%, 80\%, 90\%, and $100 \%$ ethanol solutions and acetone. The dehydrated cells were transferred to clean glass coverslip, dried and coated by Sputter coater Q150R ES (Quorum, Tokyo, Japan). All samples were kept dried in $\mathrm{CO}_{2}$ critical point dryer until they were examined by ultrahigh Resolution Scanning Electron Microscope Hitashi SEM SU8020 (Hitachi High-Tech, Tokyo, Japan). Bacterial cell morphological changes were observed.

\subsection{Evaluation of Correlations between Antioxidant and Antibacterial Activities and Phytochemical Contents}

The correlations $(\mathrm{R})$ between the parameters including total phenolic content, total flavonoid content and flavone contents and the antioxidant and antibacterial activities were evaluated by a regression method using Microsoft Excel (Microsoft Office Professional Plus 2016-Microsoft Corporation, Redmond, DC, USA).

\subsection{Statistical Analysis}

All measurements were performed in triplicate and the results are expressed as mean \pm SD. An independent sample $t$-test was used to compare the means and the least significant difference at $p<0.05$ was calculated. All analyses were performed using Microsoft Excel (Microsoft Office Professional Plus 2016-Microsoft Corporation, Redmond, $\mathrm{DC}, \mathrm{USA})$. The bacterial cell viability, the half-maximal inhibitory concentration $\left(\mathrm{IC}_{50}\right)$ and minimum inhibitory concentration (MIC) data were analyzed by dose-response non-linear regression best curve fit for inhibition activity using GraphPad Prism v.9.0.1 (GraphPad Software, CA, USA) and Calcusyn v.1.1 (Biosoft, Cambridge UK) programs. The data are presented as mean $\pm \mathrm{SD}$.

\section{Conclusions}

Extracts from the seeds collected from different locations in Thailand, and young fruits and flowers of $O$. indicum showed in vitro DPPH scavenging effects. The seed and young fruit extracts also promoted in vitro antibacterial activities against clinical isolated bacteria including $S$. intermedius, $S$. suis, P. aeruginosa, $\beta$-hemolytic E. coli and $S$. aureus. These results corresponded to our previous studies. The orange crystals and yellow precipitates were obtained from the preparation processes of both seed extracts. The orange-red crystal from the seed collected from Lampang province showed both in vitro antioxidant and antibacterial effects on the tested bacteria while the yellow precipitate from the same source showed only antioxidant activity. The formation process of these orange crystals and yellow precipitates is still unclear. Quantitative analysis of phytochemicals in O. indicum samples by spectrophotometric and HPLC techniques showed that they contained different amounts of total phenolic, total flavonoid and three major flavones, baicalin, baicalein and chrysin contents. Young fruit extract, which contained low amounts of flavone contents, still promoted antibacterial effects against the tested bacteria. Regression analysis of the 
results suggest the correlation between total phenolic and total flavonoid contents with antioxidant and antibacterial effects. Baicalin was found to have a high correlation with inhibitory effects against $\beta$-hemolytic $E$. coli while the three unidentified peaks, which could be flavones, showed high correlations with an inhibitory effect against $S$. intermedius, S. suis, P. aeruginosa and S. aureus. Scanning Electron Microscopy (SEM) suggested that the mechanism of action of $O$. indicum young fruit extract could be via flavonoid-induced bacterial cell lysis and abnormal cell aggregations. Further studies of the phytochemical and physical characteristics and other related biological activities and the mechanisms of action of the fractions and extracts from $O$. indicum are in process.

Author Contributions: Conceptualization, P.S. (Patchima Sithisarn), P.R. and P.S. (Pongtip Sithisarn); methodology, P.S. (Patchima Sithisarn), P.R. and P.S. (Pongtip Sithisarn); software; P.S. (Patchima Sithisarn) and P.R.; validation, P.S. (Patchima Sithisarn) and P.R.; formal analysis P.S. (Patchima Sithisarn), P.R. and P.S. (Pongtip Sithisarn); investigation P.S. (Patchima Sithisarn), P.R. and P.S. (Pongtip Sithisarn); resources, P.S. (Patchima Sithisarn) and P.S. (Pongtip Sithisarn); data curation, P.S. (Patchima Sithisarn), P.R. and P.S. (Pongtip Sithisarn); writing—original draft preparation, P.S. (Patchima Sithisarn), P.R. and P.S. (Pongtip Sithisarn); writing-review and editing, P.S. (Patchima Sithisarn) and P.S. (Pongtip Sithisarn); visualization, P.S. (Patchima Sithisarn) and P.S. (Pongtip Sithisarn); supervision, P.S. (Pongtip Sithisarn); project administration, P.S. (Pongtip Sithisarn); funding acquisition, P.S. (Pongtip Sithisarn). All authors have read and agreed to the published version of the manuscript.

Funding: This research received funding grant in 2020 from Biodiversity-Based Economy Development Office (Public Organization) and National Research Council of Thailand.

Institutional Review Board Statement: Not applicable.

Informed Consent Statement: Not applicable.

Data Availability Statement: Data sharing not applicable.

Acknowledgments: The authors would like to thank Juree Tungrithaiwanich and Chaweewan Suwanvecho for technical support. Authors acknowledge Biodiversity-Based Economy Development Office (Public Organization) and National Research Council of Thailand for the support.

Conflicts of Interest: The authors declare no competing financial interests.

Sample Availability: Samples of the compounds are not available from the authors.

\section{References}

1. Harminder, S.V.; Chaudhary, A.K. A review on the taxonomy, ethnobotany, chemistry and pharmacology of Oroxylum indicum Vent. Indian J. Pharm. Sci. 2011, 73, 483-490. [PubMed]

2. Warrier, P.K.; Nambiar, V.P.K.; Ramankutty, C. Indian Medicinal Plant: A Compendium of 500 Species (4); Orient Longman: Hyderabad, India, 1993; pp. 186-190.

3. Subramaniam, S.S.; Nair, A.G. Flavonoids of the stem bark of Oroxylum indicum. Curr. Sci. 1972, 41, 62-63.

4. Jayaram, K.; Prasad, M.N. Genetic diversity in Oroxylum indicum (L.) Vent. (Bignoniaceae), a vulnerable medicinal plant by random amplified polymorphic DNA marker. Afr. J. Biotechnol. 2008, 7, 254-262.

5. Bhattacharje, A.K.; Das, A.K. Phytochemical screening of some Indian plants. J. Crude Drug Res. 1969, 9, 1408-1412. [CrossRef]

6. Chen, L.J.; Games, D.E.; Jones, J. Isolation and identification of four flavonoid constituents from the seeds of Oroxylum indicum by high-speed counter-current chromatography. J. Chromatogr. A. 2003, 988, 95-105. [CrossRef]

7. Chen, L.J.; Song, H.; Lan, X.Q.; Games, D.E.; Sutherland, I.A. Comparison of high-speed counter-current chromatography instruments for the separation of the extracts of the seeds of Oroxylum indicum. J. Chromatogr. A 2005, 1063, 241-245. [CrossRef]

8. Zaveri, M.; Khandhar, A.; Jain, S. Quantification of baicalein, chrysin, biochanin-A and ellagic acid in root bark of Oroxylum indicum by RP-HPLC with UV detection. Eurasian J. Anal. Chem. 2008, 3, 245-257.

9. Tomimori, T.; Imoto, Y.; Ishida, M.; Kizu, H.; Namba, T. Studies on the Nepalese crude drug. VIII. on the flavonoid constituents of the seed of Oroxylum indicum. Shoyakugaku Zasshi. 1988, 42, 98-101.

10. Yan, R.Y.; Cao, Y.Y.; Chen, C.Y.; Dai, H.Q.; Yu, S.X.; Wei, J.L.; Li, H.; Yang, B. Antioxidant flavonoids from the seed of Oroxylum indicum. Fitoterapia 2011, 82, 841-848. [CrossRef] [PubMed]

11. Krüger, A.; Ganzera, M. Oroxylum indicum seeds-Analysis of flavonoids by HPLC-MS. J. Pharm. Biomed. Anal. 2012, 70, 553-556. [CrossRef]

12. Sithisarn, P.; Rojsanga, P.; Sithisarn, P. Inhibitory effects on clinical isolated bacteria and simultaneous HPLC quantitative analysis of flavone contents in extracts from Oroxylum indicum. Molecules 2019, 24, 1937. [CrossRef] [PubMed] 
13. Peng, Q.; Shang, X.; Zhu, C.; Qin, S.; Zhou, Y.; Liao, Q.; Zhang, R.; Zhao, Z.; Zhang, L. Qualitative and quantitative evaluation of Oroxylum indicum (L.) Kurz by HPLC and LC/qTOF/MS/MS. Biomed. Chromatogr. 2019, 33, e4657. [CrossRef] [PubMed]

14. Praserdmek, K.; Palanuvej, C.; Ruangrungsi, N. Pharmacognostic specification and chrysin content of Oroxylum indicum seeds in Thailand. J. Sci. Tech. UBU 2017, 60-68.

15. Roy, M.K.; Nakahara, K.; Na, T.V.; Trakoontivakorn, G.; Takenaka, M.; Isobe, S.; Tsushida, T. Baicalein, a flavonoid extracted from a methanolic extract of Oroxylum indicum inhibits proliferation of a cancer cell line in vitro via induction of apoptosis. Pharmazie 2007, 62, 149-153.

16. Subramanian, S.S.; Nair, A.G.R. Flavanoids of the leaves of Oroxylum indicum and Pajanelia longifolia. Phytochemistry 1972, 11, 439-440. [CrossRef]

17. Dey, A.K.; Mukherjee, A.; Das, P.C.; Chatterjee, A. Occurrence of aloe-emodin in the leaves of Oroxylum indicum Vent. Indian J. Chem. 1978, 16, 1042.

18. Yuan, Y.; Hou, W.; Tang, M.; Luo, H.; Chen, L.J.; Guan, Y.H.; Sutherland, I.A. Separation of flavonoids from the leaves of Oroxylum indicum by HSCCC. Chromatographia 2008, 68, 885-892. [CrossRef]

19. Buranrat, B.; Noiwetch, S.; Suksar, T.; Ta-ut, A. Inhibition of cell proliferation and migration by Oroxylum indicum extracts on breast cancer cells via Rac1 modulation. J. Pharm. Anal. 2020, 10, 187-193. [CrossRef]

20. Dunkhunthod, B.; Talabnin, C.; Murphy, M.; Thumanu, K.; Sittisart, P.; Hengpratom, T.; Eumkeb, G. Intracellular ROS scavenging and anti-inflammatory activities of Oroxylum indicum Kurz (L.) extract in LPS plus IFN- $\gamma$-Activated RAW264.7 macrophages. Evid. Based Complement. Altern. Med. 2020, 2020, 7436920. [CrossRef]

21. Rai, B.; Bhutia, S.; Pal, P.; Kakoti, B.B. Phytochemical analysis and antibacterial evaluation against selected gram strains by Oroxylum indicum (L.) Kurz stem bark extract, a folklore medicine of Sikkim Himalaya. J. Pharmacogn. Phytochem. 2020, 9, 11-16.

22. Kim, G.; Gan, R.Y.; Zhang, D.; Farha, A.K.; Habimana, O.; Mavumengwana, V.; Li, H.B.; Wang, X.H.; Corke, H. Largescale screening of 239 traditional Chinese medicinal plant extracts for their antibacterial activities against multidrug-resistant Staphylococcus aureus and cytotoxic activities. Pathogens 2020, 9, 185. [CrossRef]

23. Sithisarn, P.; Nantateerapong, P.; Rojsanga, P.; Sithisarn, P. Screening for antibacterial and antioxidant activities and phytochemical analysis of Oroxylum indicum fruit extracts. Molecules 2016, 21, 446. [CrossRef]

24. Rojsanga, P.; Bunsupa, S.; Brantner, A.H.; Sithisarn, P. Comparative phytochemical profiling and in vitro antioxidant activity of extracts from raw materials, tissue-cultured plants, and callus of Oroxylum indicum (L.) Vent. Evid. Based Complement. Alternat. Med. 2017, 2017, 6853212. [CrossRef] [PubMed]

25. Rojsanga, P.; Bunsupa, S.; Sithisarn, P. Flavones contents in extracts from Oroxylum indicum seeds and plant tissue cultures. Molecules 2020, 25, 1545. [CrossRef]

26. Lin, L.Z.; Harnly, J.M. A screening method for the identification of glycosylated flavonoids and other phenolic compounds using a standard analytical approach for all plant materials. J. Agric. Food Chem. 2007, 2007. 21, 1084-1096. [CrossRef]

27. Górniak, I.; Bartoszewski, R.; Króliczewski, J. Comprehensive review of antimicrobial activities of plant flavonoids. Phytochem. Rev. 2019, 18, 241-272. [CrossRef]

28. Chen, H.; He, G.; Li, C.; Dong, L.; Xie, X.; Wu, J.; Gao, Y.; Zhou, J. Development of a concise synthetic approach to access oroxin A. RSC Adv. 2014, 4, 45151-45154. [CrossRef]

29. Sun, W.; Zhang, B.; Yu, X.; Zhuang, C. Oroxin A from Oroxylum indicum prevents the progression from prediabetes to diabetes in streptozotocin and high-fat diet induced mice. Phytomedicine 2017, 38, 24-34. [CrossRef] [PubMed]

30. Yang, P.; Fu, S.; Cao, Z.; Liao, H.; Huo, Z.; Pan, Y.; Zhang, G.; Gao, A.; Zhou, Q. Oroxin B selectively induces tumorsuppressive ER stress and concurrently inhibits tumor-adaptive ER stress in B-lymphoma cells for effective anti-lymphoma therapy. Toxicol. Appl. Pharmacol. 2015, 288, 269-279. [CrossRef] [PubMed]

31. Qiu, J.Z.; Wang, D.C.; Zhang, Y.; Dong, J.; Wang, J.F.; Niu, X.D. Molecular modeling reveals the novel inhibition mechanism and binding mode of three natural compounds to Staphylococcal $\alpha$-hemolysin. PLoS ONE 2013, 8, e80197. [CrossRef] [PubMed]

32. Li, N.N.; Meng, X.S.; Bao, Y.R.; Wang, S.; Li, T.J. Evidence for the involvement of COX-2/VEGF and PTEN/Pl3K/AKT pathway the mechanism of oroxin B treated liver cancer. Pharmacogn. Mag. 2018, 14, 207-213. [PubMed]

33. Li, N.; Men, W.; Zheng, Y.; Wang, H.; Meng, X. Oroxin B induces apoptosis by down-regulating microRNA-221 resulting in the inactivation of the PTEN/PI3K/AKT pathway in liver cancer. Molecules 2019, 24, 4384. [CrossRef]

34. Li, K.; Yao, F.; Xue, Q.; Fan, H.; Yang, L.; Li, X. Inhibitory effects against $\alpha$-glucosidase and $\alpha$-amylase of the flavonoids-rich extract from Scutellaria baicalensis shoots and interpretation of structure-activity relationship of its eight flavonoids by a refined assign-score method. Chem. Cent. J. 2018, 12, 82. [CrossRef]

35. Shan, N.; Toda, F.; Jones, W. Mechanochemistry and co-crystal formation: Effect of solvent on reaction kinetics. Chem. Comm. 2002, 20, 2372-2373. [CrossRef] [PubMed]

36. Khandavilli, U.B.R.; Skořepová, E.; Sinha, A.S.; Bhogala, B.R.; Maguire, N.M.; Maguire, A.R.; Lawrence, S.E. Cocrystals and a salt of the bioactive flavonoid: Naringenin. Cryst. Growth Des. 2018, 18, 4571-4577. [CrossRef]

37. Smith, A.J.; Kavuru, P.; Wojtas, L.; Zaworotko, M.J.; Shytle, R.D. Cocrystals of quercetin with improved solubility and oral Bioavailability. Mol. Pharm. 2011, 8, 1867-1876. [CrossRef]

38. Vasisht, K.; Chadha, K.; Karan, M.; Bhalla, Y.; Jena, A.K.; Chadha, R. Enhancing biopharmaceutical parameters of bioflavonoid quercetin by cocrystallization. Cryst. Eng. Comm. 2016, 18, 1403-1415. [CrossRef] 
39. Zaini, E.; Azhari, D.; Fitriani, L. Identification and characterization of solid binary system of quercetin-nicotinamide. Orient. J. Chem. 2016, 32, 1545-1550. [CrossRef]

40. De Grano, R.V.R.; Vashchenko, E.V.; Nisar, M.; Sung, H.H.Y.; Vashchenko, V.V.; Williams, I.D. Crystal structures of the flavonoid oroxylin A and the regioisomers negletein and wogonin. Acta Cryst. 2020, 76, 490-499. [CrossRef]

41. Zhu, N.; Li, J.C.; Zhu, J.X.; Wang, X.; Zhang, J. Characterization and bioavailability of wogonin by different administration routes in beagles. Med. Sci. Monit. 2016, 22, 373-3745. [CrossRef]

42. Smith, G.; Bartley, J.P.; Wang, E.; Bott, R.C. Two crystal polymorphs of a flavonoid from Melicope ellyrana. Acta Cryst. 2001, 57, 1336-1337.

43. Tsuchiya, H. Membrane interactions of phytochemicals as their molecular mechanism applicable to the discovery of drug leads from plants. Molecules 2015, 20, 18923-18966. [CrossRef]

44. Arora, A.; Byrem, T.M.; Nair, M.G.; Strasburg, G.M. Modulation of liposomal membrane fluidity by flavonoids and isoflavonoids. Arch. Biochem. Biophys. 2000, 373, 102-109. [CrossRef] [PubMed]

45. Ollila, F.; Halling, K.; Vuorela, P.; Vuorela, H.; Slotte, J.P. Characterization of flavonoid-Biomembrane interactions. Arch. Biochem. Biophys. 2002, 399, 103-108. [CrossRef]

46. Oteiza, P.I.; Erlejman, A.G.; Verstraeten, S.V.; Keen, C.L.; Fraga, C.G. Flavonoid-membrane Interactions: A protective role of flavonoids at the membrane surface? Clin. Dev. Immunol. 2005, 12, 19-25. [CrossRef]

47. Chabot, S.; Bel-Rhlid, R.; Chenevert, R.; Piche, Y. Hyphal growth promotion in vitro of the VA mycorrhizal fungus, Gigaspora margarita Becker and Hall, by the activity of structurally specific flavonoid compounds under $\mathrm{CO}_{2}$-enriched conditions. New Phytol. 1992, 122, 461-467. [CrossRef]

48. Matijas`evic', D.; Pantic`', M.; Ras` kovic`', B.; Pavlovic`', V.; Duvnjak, D.; Sknepnek, A.; Nikšić, M. The antibacterial activity of coriolus versicolor methanol extract and its effect on ultrastructural changes of Staphylococcus aureus and Salmonella enteritidis. Front. Microbiol. 2016, 7, 1-15.

49. Mishra, A.K.; Mishra, A.; Kehri, H.; Sharma, B.; Pandey, A.K. Inhibitory activity of Indian spice plant Cinnamomum zeylanicum extracts against Alternaria solani and Curvularia lunata, the pathogenic dematiaceous moulds. Ann. Clin. Microbiol. Antimicrob. 2009, 8, 9. [CrossRef]

50. Sato, M.; Fujiwara, S.; Tsuchiya, H.; Fujii, T.; Iinuma, M.; Tosa, H.; Ohkawa, Y. Flavones with antibacterial activity against cariogenic bacteria. J. Ethnopharmacol. 1996, 54, 171-176. [CrossRef]

51. Lee, J.H.; Regmi, S.C.; Kim, J.A.; Cho, M.H.; Yun, H.; Lee, C.S.; Lee, J. Apple flavonoid phloretin inhibits Escherichia coli O157:H7 biofilm formation and ameliorates colon inflammation in rats. Infect. Immun. 2011, 79, 4819-4827. [CrossRef] [PubMed]

52. Elmasri, W.A.; Zhu, R.; Peng, W.; Al-Hariri, M.; Kobeissy, F.; Tran, P.; Hamood, A.N.; Hegazy, M.F.; Pare, P.W.; Mechref, Y. Multitargeted flavonoid inhibition of the pathogenic bacterium Staphylococcus aureus: A proteomic characterization. J. Proteome Res. 2017, 16, 2579-2586. [CrossRef]

53. Fujita, M.; Shiota, S.; Kuroda, T.; Hatano, T.; Yoshida, T.; Mizushima, T.; Tsuchiya, T. Remarkable synergies between baicalein and tetracycline, and baicalein and $\beta$-lactams against methicillin-resistant Staphylococcus aureus. Microbiol. Immunol. 2005, 49, 391-396. [CrossRef]

54. Wu, T.; Zang, X.; He, M.; Pan, S.; Xu, X. Structure-activity relationship of flavonoids on their anti-Escherichia coli activity and inhibition of DNA gyrase. J. Agric. Food Chem. 2013, 61, 8185-8190. [CrossRef]

55. Fang, Y.; Lu, Y.; Zang, X.; Wu, T.; Qi, X.; Pan, S.; Xu, X. 3DQSAR and docking studies of flavonoids as potent Escherichia coli inhibitors. Sci. Rep. 2016, 6, 23634. [CrossRef]

56. Plaper, A.; Golob, M.; Hafner, I.; Oblak, M.; Solmajer, T.; Jerala, R. Characterization of quercetin binding site on DNA gyrase. Biochem. Biophys. Res. Commun. 2003, 306, 530-536. [CrossRef]

57. Xu, H.; Ziegelin, G.; Schroder, W.; Frank, J.; Ayora, S.; Alonso, J.C.; Lanka, E.; Saenger, W. Flavones inhibit the hexameric replicative helicase RepA. Nucleic Acids Res. 2001, 29, 5058-5066. [CrossRef]

58. Chinnam, N.; Dadi, P.K.; Sabri, S.A.; Ahmad, M.; Kabir, M.A.; Ahmad, Z. Dietary bioflavonoids inhibit Escherichia coli ATP synthase in a differential manner. Int. J. Biol. Macromol. 2010, 46, 478-486. [CrossRef] [PubMed]

59. Abreu, A.C.; McBain, A.J.; Simoes, M. Plants as sources of new antimicrobials and resistance-modifying agents. Nat. Prod. Rep. 2012, 29, 1007-1021. [CrossRef] [PubMed]

60. Qian, M.; Tang, S.; Wu, C.; Wang, Y.; He, T.; Chen, T.; Xiao, X. Synergy between baicalein and penicillins against penicillinaseproducing Staphylococcus aureus. Int. J. Med. Microbiol. 2015, 305, 501-504. [CrossRef] [PubMed]

61. Eumkeb, G.; Sakdarat, S.; Siriwong, S. Reversing $\beta$-lactam antibiotic resistance of Staphylococcus aureus with galangin from Alpinia officinarum Hance and synergism with ceftazidime. Phytomedicine 2010, 18, 40-45. [CrossRef] [PubMed]

62. Huang, S.D.; Gibbons, S.; Bucar, F. Plant phenolic compounds as ethidium bromide efflux inhibitors in mycobacterium smegmatis. J. Antimicrob. Chemother. 2008, 62, 345-348.

63. Cao, Y.Y.; Dai, B.D.; Sun, X.R.; Zhu, Z.Y.; Cao, Y.B.; Wang, Y.; Gao, P.H.; Jiang, Y.Y. In vitro synergism of fluconazole and baicalein against clinical isolates of Candida albicans resistant to fluconazole. Biol. Pharm. Bull. 2008, 31, 2234-2236.

64. Chan, B.C.L.; Ip, M.; Lau, C.B.S.; Lui, S.L.; Jolivalt, C.; Ganem-Elbaz, C.; Litaudon, M.; Reiner, N.E.; Gong, H.; See, R.H.; et al. Synergistic effects of baicalein with ciprofloxacin against NorA over-expressed methicillin-resistant Staphylococcus aureus (MRSA) and inhibition of MRSA pyruvate kinase. J. Ethnopharmacol. 2011, 137, 767-773. [CrossRef] [PubMed] 
65. Dzoyem, J.P.; Hamamoto, H.; Ngameni, B.; Ngadjui, B.T.; Sekimizu, K. Antimicrobial action mechanism of flavonoids from Dorstenia species. Drug Discov. Ther. 2013, 7, 66-72. [PubMed]

66. Xin, X.; Zhang, M.; Li, X.F.; Zhao, G. Biocatalytic synthesis of lipophilic baicalin derivatives as antimicrobial agents. J. Agric. Food Chem. 2019, 67, 11684-11693. [CrossRef]

67. Baron, E.J.; Pererson, L.R.; Finegold, S.M. Bailey and Scott's Diagnostic Microbiology, 9th ed.; Baron, E.J., Pererson, L.R., Finegold, S.M., Eds.; CVMosby: St. Louis, MO, USA, 1997.

68. Bauer, A.W.; Kirby, W.M.; Sherris, J.C.; Turck, M. Antibiotic susceptibility testing by a standardized single disk method. Am. J. Clin. Pathol. 1966, 36, 493-496. [CrossRef]

69. Herigstad, B.; Hamilton, M.; Heersink, J. How to optimize the drop plate method for enumerating bacteria. J. Microbiol. Methods 2011, 44, 121-129. [CrossRef]

70. Koch, A.L. Growth measurement. In Methods for General and Molecular Bacteriology; Gerhardt, P., Murray, R.G.E., Wood, W.A., Eds.; American Society for Microbiology: Colombia, WT, USA, 1994. 